\title{
An Assessment of Challenges Faced by Security Agencies in Fighting Proliferation of Small Arms and Light Weapons in Kano State, Nigeria
}

\author{
Jibrin Ubale Yahaya ${ }^{1}$, A.N Liman ${ }^{2}$, Yahaya Adadu ${ }^{3}$ \\ ${ }^{1}$ Department of political science, Nasarawa State University, Keffi, Nigeria \\ ${ }^{2}$ Prof., Dean Faculty of Social Science, Nasarawa State University, Keffi, Nigeria \\ ${ }^{3}$ Dr., Director Consult, Nasarawa State University, Keffi, Nigeria \\ Correspondence: Jibrin Ubale Yahaya, Department of political science, Nasarawa State University, Keffi, Nigeria.
}

Received: April 6, 2018

doi:10.11114/ijsss.v6i7.3401
Accepted: June 20, 2018 Available online: July 2, 2018

URL: https://doi.org/10.11114/ijsss.v6i7.3401

\begin{abstract}
Prevention and management of crime is one of the core mandate responsibilities of security agencies who are peoples that are trained to oversee the internal security system in Nigeria. These agencies includes Nigeria Police Force, Nigeria Security and civil Defense Corps, Nigeria Immigration Service, Nigeria Customs Service, Directorate of State Security Service(DSSS) and to some certain extend when the level of internal security is over raising Nigeria Militaries, both Land Armies, Air Force and Navy gives intervention hand to curtail the situations. The widespread of small arms and light weapons in Kano State has it is genesis from both locally manufactured and the imported ones that mostly passed from various porous or illegal borders that are located in the neighboring states of Kastina and Jigawa State. SALW are the primary tools that trigger both ethnic and internal conflict and other related violent crimes that poses a threat to internal security, democracy and the operation of good governance not only in Kano State but in Nigeria. SALW is one of the key major factor s that generate to various categories of crime like armed robbery, kidder napping, community violent conflict, insurgent attacks and the host of many other crimes. The paper uses the failed state theory to explain the gap how state as an institution fails in its responsibilities and also the paper is empirical in nature by conducting interviews and administering questionnaire to some selected respondent populations from security personnel's, academicians, traditional institutions and Community Based Organization's CBO's. The paper was on the position that for democracy and good governance to be truly functional the internal security must be guaranteed by empowering security agencies in terms of increasing their number, effective training, enough working tools, good condition of service and providing policies that will address the level of poverty and unemployment in the society as well as prosecuting any member of elite that either imported the arms or given arms to youth for achieving his political interest.
\end{abstract}

Keywords: internal security, proliferation of small arms, democracy and security agencies

\section{Introduction}

Kano state was created on 27 May, 1967 from the then Northern Nigeria by the Federal Military Government. The state is located in North-Western Nigeria $-11^{0} 30^{\prime} \mathrm{N} 8030^{\prime} \mathrm{E}$ and borders Katsina State to the North-West, Jigawa State to the North-East and Bauchi and Kaduna State to the South. With an Area of 20,760 sq km. Population of approximately has over 10,000,000 (10 Million) people as at 2010populations projection. The major language is Hausa/Fulani and religion predominantly is Islam. The state has 44 Local Government Areas. The capital of Kano was circled by seven Metropolitans of Nassarawa, Dala, Tarauni, Kumbotso, Ungogo,Fagge and Municipal Council. The essence of this paper is to assess the functional roles of security agencies in Kano State towards fighting the Proliferations of Small arms and Light Weapons in the State. ( Idoko, 2014)

The availability of Small arms and Light Weapons is one of the major security challenges currently facing Nigeria, Africa and the world at large. The illegal movement and trafficking of SALW has become a trigger point that fuels the genesis of insecurity in Kano State that lead to criminal activities like communal conflict, political instability, kidder napping , armed robbery all these has contributed immensely to the level of insecurity in Kano State. (NPF, 2015)

The issue of SALW has been argued by many scholars looking at Small arms as one of the causative factor that open door for various criminal activities in the society. According to Amoa (2006) has cited that the Small arms survey of 
2004, has indicated clearly that SALW in Africa have played the major role in every political and socio-cultural conflict, from South-East and West Africa, which lead to conservative estimates that there are about 8 Million Small arms in West Africa alone out of 640 Million in circulation in the World, 100 Million are found in Africa.

The above statement is a clear indication to us that the level and number of SALW at the hands of criminals is an issue of concern that must be analyses and look forward for possible measure in order to suggest for a solution of the nature of insecurity in many African countries. The Proliferation of SALW has become one of the most urgent security and development problems affecting not only Kano State or Nigeria but almost many African countries which render the African society living in poverty, disharmony between various groups within many African countries. Ogaba (2005) argues that the problems of SALW are complex and multi dimensional in character, which is related with broad security perspective and societal issues such as conflict prevention and resolutions, poverty, gender violence issues, societal culture of violence, governance issues, criminal activities that are look links to terrorism which are also serious implications for human rights and humanitarian activities.

However, the paper want to support the argument of Ogaba that some certain social indices such as poverty, unemployment and lack of basic social needs like schools, health care, water, security and road networks if government fails to provide this services to the citizens, can lead to many energetic youth to engage in criminal activities by using available arms which is a threat to our local communities.

\section{Statement of the Problem}

The Proliferation of Small Arms and Light Weapons contributes to alarming levels of armed conflict and militancy in West Africa. African States witnessed the most destructive and violent conflicts at the tail end of the 1980s and 1990s. From the genocide in Rwanda, the almost decade long conflict in Liberia (1989-1997), the Sierra Leone crisis, the bloody crisis in the Democratic Republic of Congo, as well as the conflict in Mali, had all gone to show us the extent of how Small Arms and Light Weapons wreaking havoc on the continent, in assessing the African region in the third quarter of the twentieth century (Adejo, 2005)

BestMan W. (2006) did not hesitate to conclude that in Africa, "Development is security and security is development." Indeed there are several flash points that have remained so for a long while across the African continent. What makes these flash points thick is the availability and widespread use of Small Arms and Light Weapons. Without these Small Arms and Light Weapons, conflicts and crises would not be prolonged as they have been common happening in Africa.

It was revealed that inability of the Nigeria government and the law enforcement agencies to check the supply and the demand side of the proliferation of SALW in Nigeria has heightened and worsened the insecurity situations in the country in particular and neighboring African States (Ake, 2001)

The proliferation of Small Arms and Light Weapons poses serious challenges to both international and national security especially in most of the developing countries of the world to the extent that the states are losing their traditional monopoly over the control of the instrument of violence. Small Arms trade has been difficult to estimate and much more difficult to control. Most governments do not publish statistics on transfer of Small Arms; worst still there are private companies who are highly secretive about Arms deals, much of this trade are carried out through black markets and other illicit transfers (Anyawu, 2005)

The spread of Small Arms and Light Weapons and its degree of proliferation has reached an alarming proportion especially in the developing world of Latin America, Asia and Africa that the Small Arms and Light Weapons had undermine the peace and stability of most of the countries of the developing world directly and indirectly.(Hazen,2011)

However, in some cases, non-state actors that possess enormous Small weapons to transform political dissent into armed conflicts. Nigeria is one of the frontline victims of prolonged internal strife occasioned by Small Arms diffusion, and the worst victim of this growing violence and the attendant repercussions in Nigeria is the areas of Niger Delta Region, North-West Zone especially States like Kaduna, Kano and Zamfara Where they have Fulani rangers carrying various weapons engaging in kidnapping and armed robbery and currently North-East which is suffering from the issue of Boko Haram insurgency in places like Borno, Adamawa and Yobe which have prolonged instances of conflict that has generated insecurity not only in the zone but to the entire Nations and neighboring countries in West African Region because of wide availability of Small Arms and Light Weapons. (Sagir, 2013)

The issue of insecurity and Proliferations of Small Arms has been the subject of contentious debates among scholars. While some scholars argue that Small Arms are the direct cause of insecurity, others maintain that Small Arms are merely trigger of insecurity or precipitating factor. Despite this seeming apparent disagreement, both scholars commonly agree that the proliferation of Small Arms and Light Weapons (SALW) poses serious challenges to the sustenance of peace and stability of any society. John Keegan, a respected historian observed that:

Nuclear weapons have since 9 August 1945, killed no one. The 50,000,000 (Fifty Million) who have died in war 
since that date have for the most part, been killed by cheap, mass produced weapons and Small caliber ammunition, costing a little more than the transistor radios and dry cell batteries which have flooded the World in the same period... (Awake, 2001:5).

The implications of Small Arms and Light Weapons are often used to forcibly displace civilians, impede humanitarian assistance, prevent or delay development projects, and hinder peace - keeping and peace - building efforts. When conflicts end or subside, Small Arms often remain in circulation and this has led to additional violence and suffering... And they are frequently the primary tools of terrorists bent on sowing chaos and discord (Nte, 2011).With this we can understand that SALWV proliferation has become a tool that undermine the dignity of human rights by denying the peoples the right to live, right of movement, right of association and right to live in place of their choice within the territory of Nigeria as a result of insecurity in the country.

Attempt at curbing the proliferation of Small Arms and a light weapon has become problematic. These as result of some countries are advocating their confiscation and destruction, others encourage their manufacture, sale and distribution, and observed the trade of Small Arms and Light Weapons as a legitimate business through which their citizens make a living and sustain their economy. (Okiro, 2004:48).

As at 2002, the number of SALW in Nigeria was estimated by various reports and studies at between 1 and 3 million including Arms in lawful possession of members of the armed forces and the police and those (majority) in the hands of civilians. The $80 \%$ of SALW in civilian possession were illegally acquired because of the strict regulations (Premium Times, 2015)

The proliferation of Small Arms and Light Weapons has been moving in geometric progression and the same has being employed by the various group of criminals in Nigeria in particular and West Africa in general this bad attitude of Arms possession by criminals has poses a serious threat and challenge to the continent, which has led to exacerbating human suffering, threaten peace, security, and sustainable development. (Ayisisi, 2005)

This research work will examines sources of Small Arms and Light Weapons in Kano state in particular and Nigeria at large and how the circulation of Small Arms become a security threat to nation as well as developing new strategy of controlling the spread of Small Arms and Light Weapons for the sake of sustaining peace and security in the society. The relationship between proliferation of Small Arms and insecurity has been the object of contentious debates among scholars, while some scholars argue that Small Arms are the direct cause of insecurity, others maintain that Small Arms are merely trigger of insecurity or predisposing factor.

Kano State has 44 Local Government, with over 10 million people based on the last National Population Census of 2006 (NPC). However despite the efforts of security agencies like the Nigerian Police Force, The Nigerian Customs service, Immigration service, State Security Service, Military formations, Nigerian Security and Civil Defense Corps, the Nigerian borders have been described as porous allowing illicit Arms trafficking of Small Arms and Light Weapons in Kano State, Nigeria. There was about three major borders where Small Arms flows to Kano State from Maigatari border, Daura border, Babura border .

However, the circulated illegal Small Arms are not the only ones imported from other countries but with supplementations of locally manufactured SALW produce in areas like Wudil communities, Sumaila and Dala who are renowned local producers of Small Arms in Kano State. (Kano State, Ministry of Information, 2012)

Nigerian Police Force, Kano State Command, in its Yearly report of 2015, has indicated that in 3 years (from 2012-2015), the police in Kano State has seized illegal Small Arms both imported and locally manufactured ones, from the hands of criminals about 1,382 Arms which includes riffles, revolvers, self-loading pistol, light machine guns, local riffles, knives and cutlasses. (Gazette, 2016)

Despite all the security effort by security formations in Kano State, the police has received in one year (from 2014-2015) about 105 cases of kidnapping and armed robbery from Doguwa, Danbatta and Bichi Local Governments as a result of wide availability of Small Arms in the hands of criminals ,this has led to massive rise of insecurity in Kano State. (Gazette, 2016)

The danger of proliferation of Small Arms and Light Weapons in Kano State, has brought a serious threat to the sustenance of peaceful living in Kano State, where politicians are purchasing Arms and giving it to their political thugs to fight opponents. For instance in the Sallah Festival (Hawan Daushe) of 2017, there was a clash between Gandujiyya and Kwankwasiyya sect which has resulted to injury of over 89 peoples from both two sides among those injured was the former Secretary to Kano State Government, Dr. Rabiu Suleiman Bichi.(Daily Trust, 2016)

On 28, July 2015, Kano State Police Command, has also recovered various items, cows, laptops, 53 AK -47, 285 Ammunitions at Falgore forest, Doguwa local Government.(NPF, Kano Command, Gazette 2016) 
However, due to wide availability of Small Arms in hand of criminals in Kano you cannot spends 24 Hours in the State without security reports at list 5 cases of either Kidnapping, army robbery, attack to innocent citizens by various arms groups (Yan Daba) as a result of affordability and accessibility of Small Arms in hand of various categories of criminals.

\section{Research Questions}

The following research questions have been used to obtain relevant information's.

i. What are the factors that cause the Proliferation of Small Arms and Light Weapons that lead to insecurity in Kano State, Nigeria?

ii. What are the roles of security agencies in ensuring internal security in Kano State.?

iii. What are the implications and dangers of the proliferations of SALW on the internal security of Kano State.?

iv. Are there challenges faced by security agencies in fighting Small Arms and Light Weapons Proliferation in Nigeria?

v. What are the ways by which the proliferation of Small Arms and Light Weapons can be controlled to guarantee the internal security of Kano State.?

\subsection{Objectives of the Study}

The main objective of this research is to examine the impact of Small Arms and Light Weapons proliferation on the internal security of Kano State, Nigeria. However, the specific objectives are as follows;

i. $\quad$ To find out the major factors such as porous border and lack of effective security network between West African Countries that causes the wide spread of Small Arms and Light Weapons as a threat to internal security in Kano State, Nigeria.

ii. To critically investigate the role of security agencies in providing effective internal security in Kano State.

iii. To find out the implication and dangers associated with SALW proliferation on the internal security of Kano State.

iv. To examine the challenges faced by security agents such as lack of enough manpower and working tools as a problem in fighting proliferation of Small Arms and Light Weapons.

v. To find out ways by which the proliferation SALW can be controlled to ensure functional internal security in Kano State.

\subsection{Scope of the Study}

The study will examine the impact of proliferation of Small Arms and Light Weapons in on the internal security of Kano State, Nigeria 2010-2017.

However, due to wider coverage of Kano state with 44 Local Government Areas and over 10 Million population density, the research intended to administer interview to some security experts and community leaders as well as questionnaires to community members in security agencies selected 3 Local Governments Areas in Kano State.

\section{Literature Review and Theoretical Framework}

\subsection{Conceptual Framework}

In this part the researcher will give various definitions of the concepts that are relevant to the research work on Proliferation of Small Arms and Light Weapons in West Africa to help us make deeply investigation on the problem at hand to ensure the sustenance of Security in Nigeria.

SALW has been defined in different international and regional instruments, and also in national statutes. A common observation emerging from the different definitions is that the term "Small Arms and Light Weapons" covers a wide spectrum of weapons, their ammunitions and their spare parts. The ECOWAS Convention on Small Arms and Light Weapons, their Ammunition and other Related Materials of 2006, which is the West African sub-regional benchmark for regulating SALW, provides the following definitions:

\section{Small Arms}

This are Arms designed for personal use and which include: Fire arms and other destructive Arms or devices such as an exploding bomb, an incendiary bomb or a gas bomb, a grenade, a rocket launcher, a missile, a missile system or a mine. 1) Revolvers and pistols with automatic loading; 2) rifles and carbines; 3) machine guns; 4) assault rifles; 5) light machine guns. (ECOWAS Convention, 2006)

\section{Light Weapons}


The following portable Arms designed to be used by several people working together in a team: 1) heavy machine guns; 2)portable grenade launchers, mobile or mounted; 3) portable anti-aircraft cannons; 4) portable antitank cannons, non-recoil guns; 5) portable anti-tank missile launchers or rocket launchers; 6) portable anti-aircraft missile launchers, Mortars with a caliber of less than millimeters: projectiles and missiles for Small Arms; 3) mobile containers with missiles or projectiles for anti-aircraft or anti-tank simple action systems

Table 1. Showing Common Names and Models of Small Arms

Technical Specification

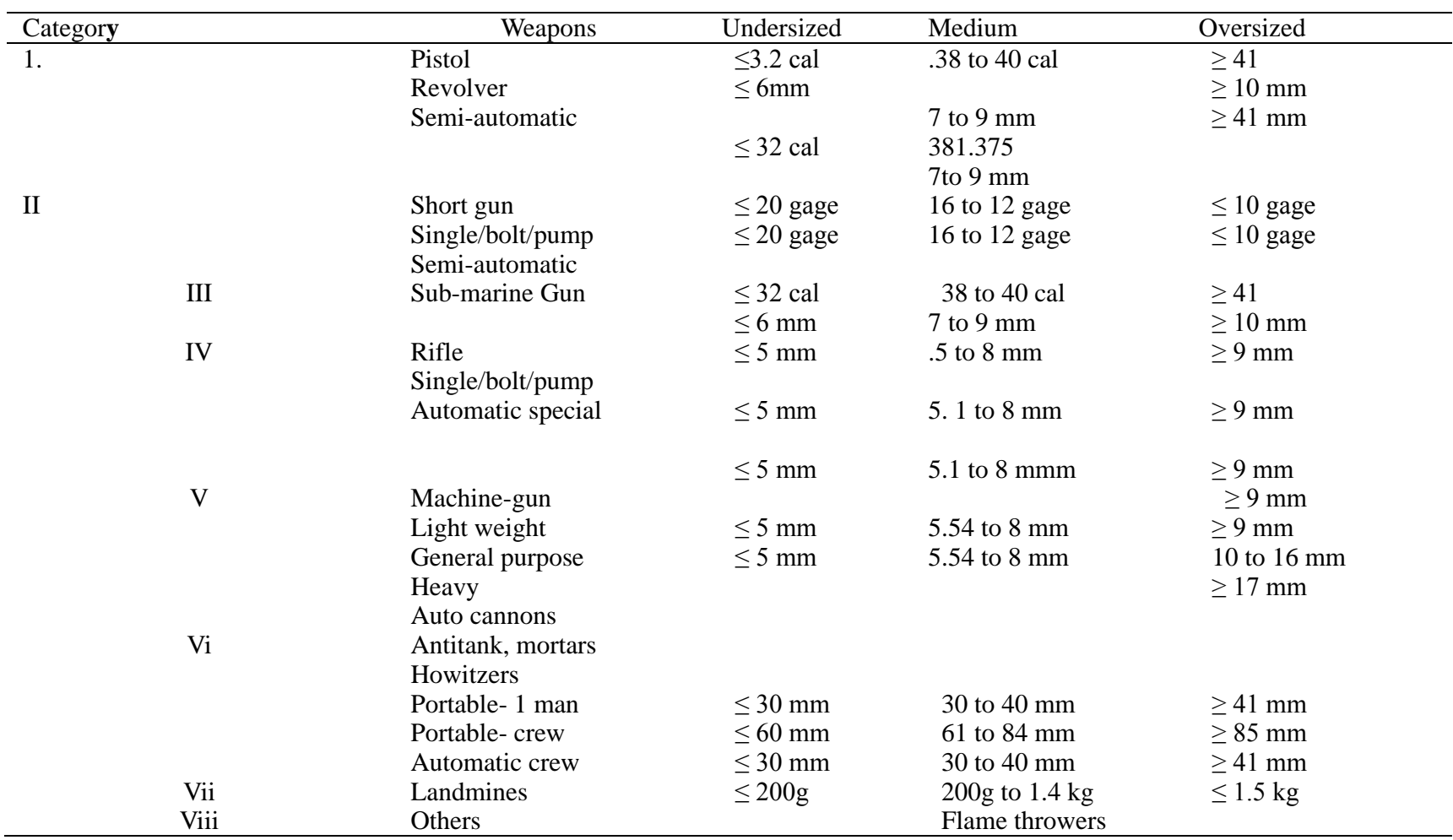

Source; UN Report 2008

\subsection{The Concept of Internal Security}

Security has to do with the process connected with alleviation, assuaging any kind of threat to man and his cherished values. It is such an important concept that every state, organization and human person desire. This is why Buzan asserts that "security is about freedom from threat and ability of state and society to maintain independent identity and their functional integrity against forces of change, which they see as hostile, while the button line is survival" (Buzan to Afolabi 2014:1)

Generally, security is an elastic concept which attracts view opinions in different fields and study and its day to day activity of men. It is referring to safety from harm and danger which may constitute threat to human existence. This is in consonance with perspective in Imobighe when he affirms that:

Security has to do with freedom from danger or threat of a nation's ability to protect and develop itself, promote its cherish values and legitimate interest and enhance the well-being of its people (lmobighe, 1990: 224).

Therefore internal security could be seen as the freedom from or absence of those tendencies which could undermine internal cohesion and the cooperate existence of a country and its ability to maintain its vital institution for the promotion of its core values and socio-political and economic objection as well as meet the legitimate operation of the people. The present challenge posed by armed robbers attacks, kidnappings, political assassinations, trans-border crimes, espionage, smuggling, insurgency, oil bunkering and incessant vandalization of public infrastructures in Nigeria require the effort of the government, security outfits and entire Nigeria citizenry. Security outfits include.

- The Nigeria Police Force

- Nigeria Security and Civil Defence Corps

- Nigeria Immigration Services

- Nigeria Prisons Services 
- Nigeria Custom Services

- Federal Road Safety Corps

- Nigeria Fire Services,

- State Peace Corps in some states and numerous registered private security organizations.

Responsible Nigerians are now skeptical about the capability of our security outfits and government of the day to curb the ugly trend.

The pre-eminent security outfits - the Nigeria Police have been incapacitated to subdue the menace of criminality in Nigeria while the Nigeria Security and Civil Defence Corps with the new armed squad men seem unfit to make an impact apart from their humanitarian services. One may infer that internal security has attracted very little attention among our leaders and academician. The porosity of Nigeria borders and infiltration of weapons and ammunitions from neighboring states account for the inefficiency of Nigeria Custom Service and Immigration Service.

The researcher, agreed with the views that activities of criminals are the major yardstick by which internal security could be measured. One of the elements of a society is the presence of criminals who are minority in number, but they are so toxic that they trouble the peaceful co-existence of the society. It should be noted that if citizens are not secure, then the state is not secure. Threats to internal security amount to the threats to National security. This study therefore examines the duties of security outfits in Nigeria and identifies their present security challenges in Nigeria. The Nigeria Police Force is the dominant security and law enforcement agency established in Nigeria. Section 114(1) of the 1999 constitution of Federal Republic of Nigeria provided that "there shall be a Police Force for Nigeria which shall be known as the Nigeria Police Force and subject to the provisions of this section..."

\subsection{Theoretical Framework}

The paper adopted failed state theory as a relevant theory guide to analyze the primary responsibility of states in the provision of security of lives and properties of the citizens, its strength and weakness as well as how state apparatus will uses security instrument tools in sustaining effective security in society.

Scholars like Catlin, Geoffrey Roberts and Palsy has their write-up describe the nature of failed state since 1980. According to Anyanwu (2005), cited "the failed state is often used to describe a state perceived as having failed at some of the basic conditions and responsibilities of a sovereign government". A failed state is the one that has shattered social and political structures. It is characterized by social, political and economic failures. The common features of failed state are when a central government is so weak or ineffective to have control over its territory.

While Musah (1999), cited in some African countries that they are perceived as failed state, because of violent crisis between arms groups and states while the thrust of international efforts to curbing proliferation of small arms tend to concentrate on the manufacture and supply of new weapons, the major pipeline of SACW remains the stockpiles that were pumped into Africa in the 70s and 80s by the ex-Soviet Union, the USA and other allies to fan or sponsor proxy interstate wars.

The relevance of failed state theory has described the failure of government at national and regional level to address the impact of proliferation of small arms and light weapons which has failed in its responsibility in providing peaceful and secured society.

\section{Methodology}

The paper will uses both primary data which will be collected from working security agencies staffs, academicians with focus area on security management, traditional institutions and civil societies groups. However the secondary data will be collected from previous research, text books, conference proceedings and government publications and gazette.

\subsection{Population of the Study}

Table II. The population of the study will be derived from the following angles

\begin{tabular}{|c|c|c|c|c|}
\hline $\mathrm{S} / \mathrm{N}$ & Population Sector & & $\begin{array}{l}\text { Number of Selected } \\
\text { Populations }\end{array}$ & Locations \\
\hline 1 & Nigeria Police & & 15 & Nigeria Police Force, Kano Command \\
\hline 2 & Immigration & & 8 & Kano Command Office. \\
\hline 3 & Custom & & 12 & Kano /Jigawa Unit \\
\hline 4 & Academia & & 3 & Bayero University/Kano Polytechnic \\
\hline 5 & Traditional Rulers & & 3 & Dala, Tudun Wada and Danbatta Local Governments. \\
\hline \multirow[t]{2}{*}{6} & $\begin{array}{l}\text { Community } \\
\text { Organizations CBO's }\end{array}$ & Based & 2 & $\begin{array}{l}\text { Inuwar Jama'ar Kano (Kano Peoples Forum) andKano } \\
\text { Progressive Movement. }\end{array}$ \\
\hline & Total & & 43 & \\
\hline
\end{tabular}


Source: Field Research, May 2018.

\subsection{Method of Data Collection}

The researcher will combined both interviews and administering the questionnaire tool to derived the needed information on the subject matter.

\section{Sample and Sample Technique}

The Sample of this study was drawn from the population specified in the above table 1 .

\section{Research Instrument}

A researcher designed a questionnaire to use in this study, with assistant of experts who has tested and measured to ensure its reliability and validity. Each respondent, responded by indicating his/her degree of agreement or disagreement with each statement by marking tick.

Strongly Agree (SA) 5 Points

$\begin{array}{ll}\text { Agree } & \text { (A) } 4 \text { Points } \\ \text { Disagree } & \text { (D) } 3 \text { Points } \\ \text { Strongly Disagree (SD) } & 2 \text { Points } \\ \text { Undecided } & \text { (U) } 1 \text { Point }\end{array}$

Table III. Major Challenges Faced by Security agencies in Kano State Nigeria

\begin{tabular}{|c|c|c|c|c|c|c|c|c|}
\hline $\mathrm{S} / \mathrm{N}$ & Challenges faced by security agencies & SA & A & $\mathrm{D}$ & SD & $\mathrm{U}$ & Frequency & Percentage \\
\hline \multirow[t]{2}{*}{1} & Lack of enough staffs strength & 13 & 25 & 5 & & & 43 & $100 \%$ \\
\hline & & $30 \%$ & $58 \%$ & $12 \%$ & & & & \\
\hline \multirow[t]{2}{*}{2} & Lack of working tools & 30 & 10 & & 3 & & 43 & $100 \%$ \\
\hline & & $70 \%$ & $23 \%$ & & $7 \%$ & & & \\
\hline \multirow[t]{2}{*}{3} & Porous Border & 35 & 6 & 2 & & & 43 & $100 \%$ \\
\hline & & $81 \%$ & $14 \%$ & $5 \%$ & & & & \\
\hline \multirow[t]{2}{*}{4} & Lack of training and Professionalism & 15 & 20 & 6 & 2 & & 43 & $100 \%$ \\
\hline & & $35 \%$ & $47 \%$ & $14 \%$ & $4 \%$ & & & \\
\hline \multirow[t]{2}{*}{5} & Poor Condition of Service & 28 & 12 & 2 & 1 & & 43 & $100 \%$ \\
\hline & & $65 \%$ & $28 \%$ & $5 \%$ & $2 \%$ & & & \\
\hline \multirow[t]{2}{*}{6} & God Political Fathers & 18 & 10 & 11 & 4 & & 43 & $100 \%$ \\
\hline & & $42 \%$ & $23 \%$ & $26 \%$ & $9 \%$ & & & \\
\hline
\end{tabular}

Source: Field Interviews and Questionnaires May 2018.

\section{Discussion of Findings}

The focus point of this paper was to look at the problems faced or encounter by security agencies in the process of fighting crimes especially the proliferation of small arms and light weapons in Kano State in particular and the entire country Nigeria. Looking at the above problems facing security agencies in Kano State, the issue of porous border which has $81 \%$ this indicate many arms flows to Kano State through some unknown borders which are illegal exits by criminal importers or from crises prone countries like Libya and Niger Republic. Secondarily, the issues of lack of working tools has $70 \%$ which shows the security agencies does not have enough working arms to fight the emerging crimes in the state because in some instances the criminals has stronger arms than the conventional security because of lack of political will and commitment from the policy makers. Thirdly, poor condition of service, most of the security are lacking job satisfaction because they are receiving very low salaries, non-payment of allowances, over delay in pension benefits, delay in promotions and lack of accommodations in various working places. However, again the security agencies are not enough to address the security challenges facing the Community of Kano with over 10 Million Populations with entire rate of security personal's not more than 11 thousands this is something that must be look in to for peoples to live in peace and harmony. Another issue that disturbs the security agencies role in fighting crime in Kano State is the engagement of political elite of providing arms to be given to various category youth to advocate and protect their political interest that become difficult for security agencies in making deep investigation and also the prosecution of the cases at the competent court of law.

\section{Conclusion}

The issue of Small arms and Light Weapons is an issue that really affects both the security atmosphere and the process of how government conducts its affairs. The current security threats in Nigeria is becoming the new dimension of insecurity and criminal act engagement as a result of availability of Small Arms and Light Weapons (SALW) where open availability of Small Arms has lead to emergence of various criminal activities like armed robbery, ethno-religious conflicts, militancy, assassinations, cultism, human trafficking, terrorism and kidnapping. This security threats considered to be relatively new 
in Nigeria - though not without precedent, in the strict sense of it the policy makers fails to develop a means of addressing the emerging security threat of abundant use of Small Arms through adopting laws that will restrict the wide availability of Small Arms. Secondly the issue of lack of commitment from the side of government and other stakeholders has resulted in the outbreak of religious extremism and other domestic terrorism, evident in the growing audacity of the "Boko Haram" sect including the 50th Independence Day (1 October 2010) twin bomb blasts in Abuja that killed 12 people, the last (14 April 2014) Nyanya Motor Park bombing that claimed more than 75 lives and injured several dozen others and the abduction of over 200 girls of GGSS in Chibok, Borno State, and the recent new kidnapping of over 100 girls secondary school students in Yobe State all this happen because of wide availability of Small Arms in Nigeria as a result of weak policies and poor security formation structures in the country.

\section{Recommendations}

This paper has recommended the following strategy to address the problems of Small arms Proliferations in Kano State, Nigeria and Africa at Large:

i. There should be a national body that has the power to regulate the inflow of Small arms and Light Weapons in the country.

ii. There should be commitment from politician to take the issue of Small arms proliferations as one of the major factor that lead to emerging of various crimes in the countries in Africa.

iii. $\quad$ Porous borders should be identified and close the gap by ensuring no illegal items will flow to any African countries.

iv. There should be security networking between various security agencies in Nigeria and Africa to make collaborative efforts in fighting Small arms in Nigeria and Africa at Large.

v. Government should empowered security agencies in terms of training, man power strength, working tools and good conditions of service in Nigeria and Africa at large.

vi. Prosecuting any politician or member of the elite group who engage of importing illegal Small arms or provide the arms to unemployed youth to pursuit his political through violence in the court of law.

vii. Government should provide policies that will address the level of poverty and unemployment to reduce the level of crime by our energetic youth in Nigeria and Africa at large.

viii. Government should developed disarmed program by allowing armed individuals or groups to submit the arms to a designated point and take an oath of not using illegal arms again and reintegrate to normal social live.

ix. Engaging traditional and Community Based Organization's CBO's in fighting the proliferations of small arms in their respective communities.

\section{References}

Adebe, M. (2012). The dangers of Arms proliferation in Africa, levty Bookshops Printers limited, Uganda.

Adejo, P. Y. (2005). "Crime and Cross-Border Movement of Weapons: The Case of Nigeria” in A. Ayissi and I, Sall (eds), Combating the Proliferation of Small Arms and Light Weapons in West Africa: Handbook for the Training of Armed and Security Forces, Geneva: United Nations Institute of Disarmament Research (UNIDIR).

Aderinwale, A. (2005). "Civil Society and the Fight against the Proliferation of Small Arms and Light Weapons" Combating the Proliferation of Small Arms and Light Weapons in West Africa: Handbook for the Training of Armed and Security Forces, Geneva: United Nations Institute of Disarmament Research (UNIDIR).

Ake, C. (1981). A Political Economy of Africa, London: Longman Group.

Ake, C. (1985). Political Economy of Nigeria, London: Longman Group.

Ake, C. (2001). Democracy and Development in Africa, Ibadan: Spectrum Books.

Akpan, S. (2011). The Niger Delta Question and the peace Plan, Safari Books (Exports) Limited, Jersery, United Kingdom.

Albert, A. (2012) How Boko Haram imports Arms from Wharf using petrol tankers, across Borders using camels, retrieved from vanguard News Paper.

Aniche,M. (2012). issues of conflicts in Nigeria, King Press limited, Nigeria.

Anyanwu, U. (2005). "Failed States in Africa: The Nigerian Case since 1960". American Journal of International Politics and Development Studies (AJIPDS), 1(1). 
Ayissi, A., \& Sall, I. (eds) (2005). Combating the Proliferation of Small Arms and Light Weapons in West Africa: Handbook for the Training of Armed and Security Forces, Geneva: United Nations Institute of Disarmament Research (UNIDIR).

Bashir, M. (2014). Small Arms and Light Weapons proliferation and its implication for West-African Regional Security. E-international Journal of Humanities and Social Science, 4(8), 260-269. Retrieved from http//ijhssnet.com/journals

Bassey, L. (2007). Conflict Resolution, identity crisis and Development in Africa, Malhouse Press limited, Lagos, Nigeria.

Bestman, W, (2006). "Weapons of War in the Niger Delta” IIRIN, May 2006, quoted in Bestman Wellington's article, "Weapons of war in The Niger Delta".

Christopher, L. (2011). The social Impacts of Light Weapons Availability and Proliferation, International Alert. A Discussion paper for UNIDIR.

Chuma-Okoro, H. (2011). "Proliferation of Small Arms and Light Weapons in Nigeria: Legal Implications" in Law and Security in Nigeria.

Daily Trust, Newspaper, May 24, 2017 p-1-6.

Docubo, C. (2003). The role of Nigerian Security and the impact of community engagement in providing effective security, Spectrum Printers, Ibadan, Nigeria.

Dunn, S. (2014). Analysis of ethnic and religious conflict in Nigeria, Using Alternative Conflict Resolution, Gaskiya Printers, Kaduna, Nigeria.

ECOWAS, Convention on Small Arms and Light Weapons, October 1998, Abuja, Nigeria.

Falola, Y. (2009). Small Arms proliferations and it is implication to the nation security and peaceful existence, fedreix printers ,Lagos, Nigeria.

Florquin, N., \& Berman, E. G. (eds) (2005). Armed and Aimless: Armed Groups, Guns, and Human Security in the ECOWAS Regions, Geneva: Small Arms Survey Publication.

Funso, L. (2007). Conflict and crisis management in Nigeria,Edward Press, Lagos, Nigeria.

Hazen, G. (2011). Small Arms, armed violence and insecurity in Nigeria, the Nigerian Perspectives" Small Arms survey, occasional, paper 20. Graduate Institute of International Studies. Swizer Land, Geneva.

Hazen, J. M., \& Horner, J. (2007). "Small Arms, Armed Violence, and Insecurity in Nigeria: The Niger Delta in Perspective" The Small Arms Survey Occasional Paper 20.Ibrahim, M. (2003) Democracy and the Menace of Small Arms of Small Arms proliferation in Nigeria, Lagos: Centre for Democracy and Development.

Idoko, G. (2014). The proliferation of small arms and light weapons in Nigeria, a threat to National Security, in Kano State, Unpublished M.sc Thesis.

John, I. A. Mohammed, A. Z., Pinto, A. D., \& Nkanta, C. A. (2007). Gun Violence in Nigeria: A focus on ethno religious conflict in Kano. Journal of Public Health Policy, 28, 420-431. https://doi.org/10.1057/palgrave.jphp.3200155

Kofi, A. (2010). Millennium report to UN General Assembly (UNGA), New York, USA.

Krause, N. (2007). Small Arms and Light Weapons proliferations in West Africa, Utara university Prints, Malaysia.

M. C. Governor. (2013). Insecurity and challenge of peaceful living in the society, Prose Prints, London.

Marx, K., \& Engels, F. (1977). Manifesto of the Communist Party, Moscow: Progress Publishers.

Moulaye, S. (2006). Moving Nations Forward through effective security networking in Nigeria, Akeyinde Prints, Lagos, Nigeria.

Ndime, D. (2005). "Corporation between States to Combat the Proliferation of Small Arms and Light Weapons" in A. Ayissi and I. Sall (eds) Combating the Proliferation of Small Arms and Light Weapons in West Africa: Handbook for the Training of Armed and Security Forces, Geneva: United Nations Institute of Disarmament Research (UNIDIR).

Ngang, C. K. (2002). Small Arms and Light Weapons, Africa's True WMDs: The Role of SALW in Conflict and Insecurity in Sub-Saharan Africa ,MA Thesis, European University Center for Peace Studies (EPU), Stadstschlaining, Austria.

Nigerian Police Force, Kano Command, Annual Reports of 2015-2016.

Nte, N. D. (2011). "The Changing Patterns of Small and Light Weapons (SALW) Proliferation and the Challenges of National Security in Nigeria". Global Journal of Africa Studies, 1(1), 5-2. 
Obasi, I. N. (1999). Research Methodology in Political Science, Enugu: Academic Publishing Company.

Ocheche, S. (2005). "Cooperating with Civilians and the Security Forces in Efforts to Combat the Proliferation of Small Arms and Light Weapons" in A. Ayissi and I. Sall (eds) Combating the Proliferation of Small Arms and Light Weapons in West Africa: Handbook for the Training of Armed and Security Forces, Geneva: United Nations Institute of Disarmament Research (UNIDIR).

Okoro, H. (2004). Proliferation of Small Arms and Light Weapons in Nigeria; legal implications in Law and security in Nigeria, Enugu.

Okunmu, W. (2010). African's problematic Borderlines, in F.C Onuoha, porous Borders and Boko Haram's Arms smuggling operations in Nigeria, op. cit.

Onuoha, F. C. (2015). Corruption and National Security. The three -Gap thesis and the Nigerian experience, in F.C Onuoha, Small Arms and Light Weapons proliferation and Human Security in Nigeria, op. cit.

\section{Copyrights}

Copyright for this article is retained by the author(s), with first publication rights granted to the journal.

This is an open-access article distributed under the terms and conditions of the Creative Commons Attribution license which permits unrestricted use, distribution, and reproduction in any medium, provided the original work is properly cited. 